\title{
Autocrine Effects of Visfatin on Hepatocyte Sensitivity to Insulin Action
}

\author{
V. ŠKOP ${ }^{1}$, K. KONTROVÁ ${ }^{1}$, V. ZÍDEK ${ }^{2}$, M. PRAVENEC ${ }^{2}$, L. KAZDOVÁ $^{3}$, K. MIKULÍK $^{4}$, \\ J. SAJDOK ${ }^{1}$, J. ZÍDKOVÁ ${ }^{1,2}$ \\ ${ }^{1}$ Institute of Chemical Technology, Department of Biochemistry and Microbiology, Prague, Czech \\ Republic, ${ }^{2}$ Institute of Physiology, Academy of Sciences of the Czech Republic, Prague, Czech \\ Republic, ${ }^{3}$ Institute for Clinical and Experimental Medicine, Prague, Czech Republic, ${ }^{4}$ Institute of \\ Microbiology, Czech Academy of Sciences of the Czech Republic, Prague, Czech Republic
}

Received July 2, 2009

Accepted November 12, 2009

On-line November 20, 2009

\section{Summary}

Visfatin was originally described as an adipokine with insulin mimetic effects. Recently, it was found that visfatin is identical with the Nampt (nicotinamide phosphoribosyltransferase) gene that codes for an intra- and extracellular NAD biosynthetic enzyme and is predominantly expressed outside the adipose tissue. In the current study, we found strong protein and mRNA expression of visfatin in rat heart, liver, kidney, and muscle, while the expression of visfatin in visceral fat was significantly lower and undetectable in subcutaneous fat. The insulin-mimetic effects of visfatin (extracellular form of Nampt or eNampt) are controversial and even less is known about autocrine effects of visfatin (intracellular form of Nampt or iNampt). Since liver plays a major role in glucose metabolism, we studied visfatin effects on insulin-stimulated cellular glucose uptake in Fao rat hepatocytes using RNA interference (RNAi). RNAi-mediated downregulation of visfatin expression in Fao cells was associated with significantly reduced NAD biosynthesis $(0.3 \pm 0.01$ vs. $0.5 \pm 0.01 \mathrm{mmol} / \mathrm{h} / \mathrm{g}$, $\mathrm{P}<0.05)$ and with significantly decreased incremental glucose uptake after stimulation with insulin when compared to controls with normal expression of visfatin $(0.6 \pm 0.2$ vs. $2.2 \pm 0.5$ $n n m o l / g / 2 h, P=0.02$ ). These results provide evidence that visfatin exhibits important autocrine effects on sensitivity of liver cells to insulin action possibly through its effects on NAD biosynthesis.

\section{Key words}

Visfatin • Fao hepatocytes • Insulin resistance • RNA interference

\section{Corresponding authors}

M. Pravenec, Institute of Physiology, Academy of Sciences of the Czech Republic, Vídeňská 1083, 14220 Prague 4, Czech Republic. E-mail: pravenec@biomed.cas.cz

or

J. Zídková, Institute of Chemical Technology, Department of Biochemistry and Microbiology, Technická 3, 16628 Prague 6, Czech Republic. E-mail: jarmila.zidkova@vscht.cz

Adipokines are bioactive mediators released from adipose tissue. The effects of adipokines on vascular function, immune system regulation and adipocyte metabolism make them key players in the pathogenesis of metabolic syndrome (Rajala et al. 2003). Recently, Fukuhara et al. (2005) reported identification of a new adipokine named visfatin (visceral fat adipokine). Several subsequent studies have focused on clarifying the expression, secretion and function of visfatin in glucose and lipid metabolism, but with conflicting results (Sethi et al. 2005, Arner 2006, Brendt et al. 2006, Chen et al. 2006, Stephens et al. 2006). Later on, visfatin was found to be identical with the presumptive cytokine PBEF (pre-B cell colony-enhancing factor) (Samal et al. 1994) and finally with the Nampt (nicotinamide phospho-ribosyltransferase) gene that is expressed predominantly outside the adipose tissue and that codes for an enzyme involved in nicotinamide adenine dinucleotide (NAD) biosynthesis

PHYSIOLOGICAL RESEARCH • ISSN 0862-8408 (print) • ISSN 1802-9973 (online)

(c) 2010 Institute of Physiology v.v.i., Academy of Sciences of the Czech Republic, Prague, Czech Republic

Fax+420 241062 164, e-mail: physres@biomed.cas.cz, www.biomed.cas.cz/physiolres 
(Rongvaux et al. 2002). Recently, Revollo et al. (2007) demonstrated that extracellular visfatin (eNampt) does not exert insulin-mimetic effects in vitro when exogenously administered visfatin showed no effects on differentiation of the human SGBS preadipocyte cell line or on glucose uptake in 3T3-L1 adipocytes. Fukuhara et al. (2005) reported insulin mimetic effects of visfatin also in liver cells when exogenous visfatin suppressed glucose release in H4IIEC3 hepatocytes. In the current study, we analyzed the expression of visfatin in rat tissues and studied visfatin effects on cellular glucose uptake and insulin sensitivity in Fao rat hepatocytes using RNA interference (RNAi)mediated down regulation of visfatin expression.

A.

C.

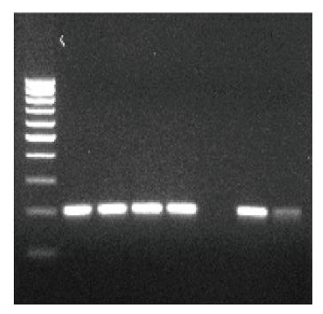

$\begin{array}{llllllll}M & 1 & 2 & 3 & 4 & 5 & 6 & 7\end{array}$

B.

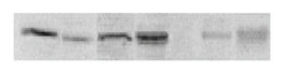

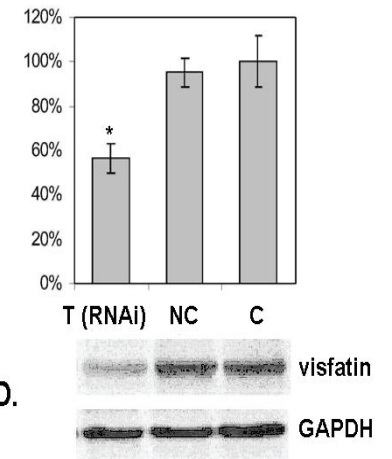

Fig. 1. Expression of visfatin in tissues isolated from WKY rats. A. Agarose gel electrophoresis of visfatin-specific PCR products after reverse transcription from rat tissue mRNA. M - 1Kb DNA Ladder, 1 - heart, 2 - brain, 3 - kidney, 4 - liver, 5 subcutaneous fat, 6 - striated muscle, 7 - visceral fat. B. Western blot analysis of tissue protein extracts. Protein visfatin was immunodetected by a polyclonal antibody using chemiluminescent detection. 1 - heart, 2 - liver, 3 - kidney, 4 subcutaneous fat, 5 - striated muscle, 6 - visceral fat, 7 - brain. C. Relative quantification of visfatin gene expression in Fao hepatocytes following qRT-PCR analysis being determined in triplicates. Each sample was normalized to the expression of the house keeping gene. $T$ - cells transfected with pSilencer containing sequence interfering with visfatin mRNA expression; NC - negative control, cells transfected with pSilencer-4.1 containing nonsense sequence; $C$ - control cells. Results are expressed as means \pm S.E.M. * denotes $\mathrm{P}<0.05$ by Student $\mathrm{t}$ test. D. Western blot analysis of Fao hepatocyte cell lysates. Expression of visfatin and GAPDH (as a loading control) was immunodetected by polyclonal antibodies. Cell lysates were prepared from cells harvested after G418 selection. QRT-PCR, western blot analyses and RNAi were perfomed as described previously (Kontrová et al. 2007). Briefly, a Fao rat hepatocyte cell line was grown in HAM:F12 medium supplemented with $10 \%$ fetal bovine serum (FBS) at $37{ }^{\circ} \mathrm{C}$ in a humidified $5 \% \mathrm{CO}_{2}, 95 \%$ air incubator. Plasmids were prepared by cloning sequences complementary to rat PBEF-1 (GenBank BC085681): sense 5'-GATCCGGTTACTCACTATAAACAATTCAAGAGATTGTTTATAGTGA GTAACCTTA-3' and antisense 5'-AGCTTAAGGTTACTCACTATAAAC AATCTCTTGAATTGTTTATAGTGAGTAACCG-3' into BamHI and HindIII sites in pSilencer ${ }^{\mathrm{TM}}$ 4.1-CMV-neo vectors (Ambion). After transfection, the cells were incubated with DNA:FuGeneHD mixture for $48 \mathrm{~h}$ and 2 days in medium with $50 \mu \mathrm{g} / \mathrm{ml}$ of antibiotic G418. Transfected cells were selected in F12:HAM containing $10 \% \mathrm{FBS}$ and $120 \mu \mathrm{g} / \mathrm{ml}$ of G418.

Figures $1 \mathrm{~A}$ and $1 \mathrm{~B}$ show the expression of visfatin mRNA and protein in tissues isolated from WistarKyoto (WKY) rats detected by agarose gel electrophoresis of the PCR products through reverse transcription of the total RNA and by Western blot analysis. As can be seen, no visfatin-specific PCR product was detected in the subcutaneous fat tissue. The absence of visfatin protein in subcutaneous fat tissue was also confirmed by Western blot analysis (Fig. 1B). Visfatin expression was significantly increased in heart, liver and kidney compared to muscle, brain, and visceral fat. These expression results in WKY rats are in agreement with those reported by Revollo et al. (2007) in the mouse.

A.
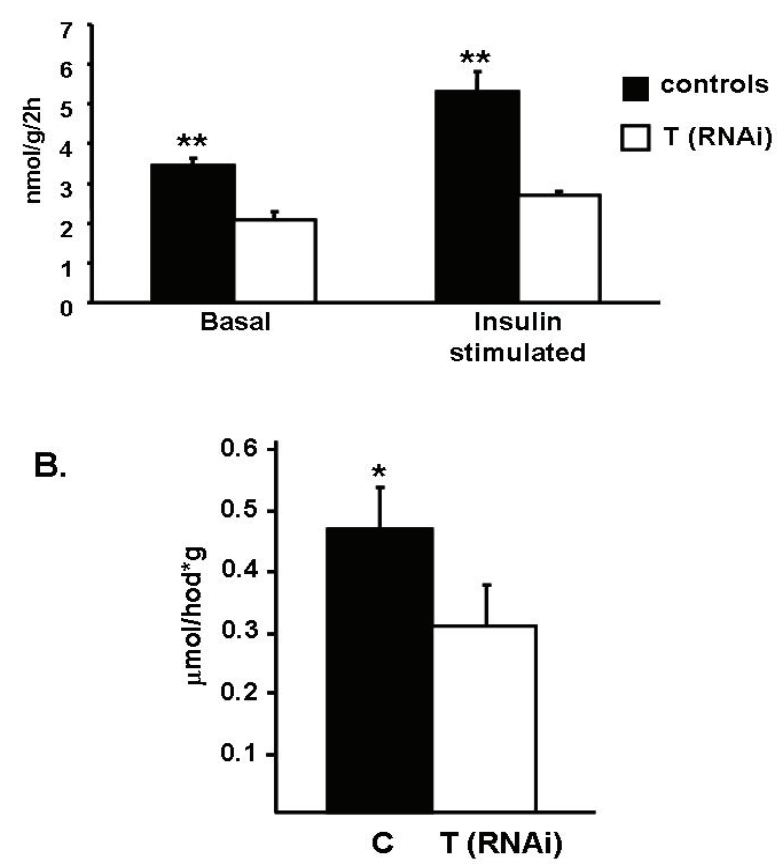

Fig. 2 A. Basal and insulin-stimulated glucose uptake by Fao hepatocytes being determined in triplicates. Hepatocytes with normal expression of visfatin exhibited significantly increased both basal and insulin-stimulated glucose incorporation as well as incremental glucose incorporation after insulin stimulation. Glucose uptake by Fao hepatocytes was performed as described previously (Kontrová et al. 2007). B. Rates of NAD biosynthesis in Fao hepatocytes determined using the fluorescence method. C - control cells; $\mathrm{T}$ - cells transfected with pSilencer-4.1 containing sequence interfering with visfatin mRNA expression. Results being determined in triplicates are expressed as means \pm S.E.M. * and ** denote $\mathrm{P}<0.05$ and $\mathrm{P}<0.0005$ by Student $\mathrm{t}$ test, respectively. Rate of NAD synthesis was measured by a fluorescence method. The reaction was performed in a 96-well microplate at $37^{\circ} \mathrm{C}$ with gentle shaking. Each well contained $200 \mu \mathrm{l}$ of cell lysate in a reaction buffer $(50 \mathrm{mM}$ Tris-HCl, $\mathrm{pH} 8.8$, $20 \mathrm{mM} \mathrm{MgCl}$ and $50 \mathrm{nM}$ protease inhibitors), alcohol dehydrogenase from yeast $(20 \mathrm{U})$ and substrate mixture $(5 \mathrm{mM}$ 5-phospho- $\alpha$-D-ribose-1-diphosphate, $4 \mathrm{mM}$ ATP, $50 \mathrm{mM}$ nicotinamide, $1 \%$ ethanol). NADH fluorescence was measured for $16 \mathrm{~h}$ with a Fluoroskan Ascent FL type 374 fluorimeter (Thermo Electron Corporation) using a filter with an excitation wavelength of $355 \mathrm{~nm}$ and an emission wavelength of $460 \mathrm{~nm}$. 
To test possible autocrine effects of visfatin (iNampt) on glucose uptake and insulin sensitivity in liver cells, we analyzed whether downregulation of visfatin expression by RNAi could affect glucose incorporation into Fao hepatocytes and how this will be modified in the presence of insulin. The efficiency of the silencing of the visfatin gene expression by RNAi was evaluated at the protein level by Western blot analysis and at the mRNA level by qRT-PCR. Experiments included untreated control cells, and as a negative control, cells transfected with a nonsense sequence. Figures $1 \mathrm{C}$ and $1 \mathrm{D}$ show significantly decreased levels of both RNA and protein in transfected Fao hepatocytes confirming significant downregulation of visfatin. The role of visfatin in cellular glucose uptake was analyzed by measuring incorporation of radioactively labeled ${ }^{14} \mathrm{C}$-glucose into Fao hepatocytes in the presence or absence of insulin in the incubation media. Figure 2A shows that Fao hepatocytes with downregulated visfatin expression exhibited significantly reduced levels of cellular glucose uptake and were insulin resistant because the incremental increase in glucose incorporation after insulin stimulation was significantly lower compared to control hepatocytes $(0.6 \pm 0.2$ vs.
$2.2 \pm 0.5 \mathrm{nnmol} / \mathrm{g} / 2 \mathrm{~h}, \mathrm{P}=0.02)$. These results indicate that autocrine effects of visfatin may play an important role in regulating insulin sensitivity in the liver. It can be hypothesized that insulin-sensitizing effects of visfatin are related to its essential role in the NAD biosynthetic pathway. Accordingly, we also tested whether RNAi induced downregulation of visfatin affects NAD biosynthesis. As can be seen in Figure 2B, NAD biosynthesis rate was significantly reduced in the Fao hepatocytes with downregulated levels of visfatin. These results provide evidence that visfatin exhibits important autocrine effects on sensitivity of liver cells to insulin action possibly through its effects on NAD biosynthesis.

\section{Conflict of Interest}

There is no conflict of interest.

\section{Acknowledgements}

This study was supported by grant A500110805 from the Grant Agency of the Czech Academy of Sciences, by grant ME08006 from the Ministry of Education of the Czech Republic and by grants 9387-3 and 9359-3 from the Ministry of Health of the Czech Republic.

\section{References}

ARNER P: Visfatin-a true or false trail to type 2 diabetes mellitus. J Clin Endocrinol Metab 91: 28-30, 2006.

BRENDT J, KLOTING N, KRALISCH S, KOVACS P, FASSHAUER M, SCHON M, STUMVOLL M, BLUHER M: Plasma visfatin concentrations and fat depot-specific mRNA expression in humans. Diabetes 54: 2911-2916, 2006.

CHEN M, CHUNG F, CHANG D, TSAI J, HUANG H, SHIN S, LEE Y: Elevated plasma level of visfatin/pre-B cell colony-enhancing factor in patients with type 2 diabetes mellitus. J Clin Endocrinol Metab 91: 295-299, 2006.

FUKUHARA A, MATSUDA M, NISHIZAWA M, SEGAWA K, TANAKA M, KISHIMOTO K, MATSUKI Y, MURAKAMI M, ICHISAKA T, MURAKAMI H, WATANABE E, TAKAGI T, AKIYOSHI M, OHTSUBO T, KIHARA S, YAMASHITA S, MAKISHIMA M, FUNAHASHI T, YAMANAKA S, HIRAMATSU R, MATSUZAWA Y, SHIMOMURA I: Visfatin: a protein secreted by visceral fat that mimics the effects of insulin. Science 307: 426-430, 2005.

KONTROVÁ K, ZÍDKOVÁ J, BARTOŠ B, ŠKOP V, SAJDOK J, KAZDOVÁ L, MIKULÍK K, MLEJNEK P, ZÍDEK V, PRAVENEC M: CD36 regulates fatty acid composition and sensitivity to insulin in 3T3-L1 adipocytes. Physiol Res 56: 493-496, 2007.

RAJALA M, SCHERER P: The adipocyte - at the crossroads of energy homeostasis, inflammation and atherosclerosis. Endocrinology 144: 3765-3773, 2003.

REVOLLO JR, KÖRNER A, MILLS KF, SATOH A, WANG T, GARTEN A, DASGUPTA B, SASAKI Y, WOLBERGER C, TOWNSEND RR, MILBRANDT J, KIESS W, IMAI S: Nampt/PBEF/visfatin regulates insulin secretion in $\beta$ cells as a systemic NAD biosynthetic enzyme. Cell Metab 6: 363-375, 2007.

RONGVAUX A, SHEA RJ, MULKS MH, GIGOT D, URBAIN J, LEO O, ANDRIS F: Pre-B-cell colony-enhancing factor, whose expression is upregulated in activated lymphocytes, is a nicotinamide phosphoribosyltransferase, a cytosolic enzyme involved in NAD biosynthesis. Eur J Immunol 32: 3225-3234, 2002. 
SAMAL B, SUN Y, STEARNS G, XIE C, SUGGS S, MCNIECE I: Cloning and characterization of the cDNA encoding a novel human pre-B-cell colony-enhancing factor. Mol Cell Biol 14: 1431-1437, 1994.

SETHI J, VIDAL-PUIG A: Visfatin: the missing link between intra-abdominal obesity and diabetes? Trends Mol Med 11: 344-347, 2005.

STEPHENS JM, VIDAL-PUIG AJ: An update on visfatin/pre-B cell colony enhancing factor, an ubiquitously expressed, illusive cytokine that is regulated in obesity. Curr Opin Lipidol 17: 128-131, 2006. 